\title{
The Role of Domestic Investment is on Reducing Poverty in 9 Provinces in Java, Bali, NTT and NTB
}

\author{
Suryatno Wiganepdo $\mathrm{S}^{1}$, Sugiyanto ${ }^{2}$ \\ \{surwiga@gmail.com ${ }^{1}$, sugiyanto@borobudur.ac.id²\} \\ Universitas Borobudur, Jakarta, Indonesia ${ }^{1,2}$
}

\begin{abstract}
The goal of this research is to determine the role of domestic investment in poverty reduction in nine provinces across Java, Bali, East Nusa Tenggara (NTT), and West Nusa Tenggara (NTB). This study employs quantitative approaches, drawing on data from the Central Bureau of Statistics, Bank Indonesia, and the Ministry of Finance. Manpower and Transmigration. The analysis used the method of panel least square dummy variables by conducting a combination analysis of time series data and cross section data by taking samples in 9 Provinces in Java, Bali, NTT and NTB. The amount of data used is a ten-year span, i.e., from 2010 to 2019 . The results of the study proved that when there was an increase in domestic investment in 9 provinces in Java, Bali, NTT and NTB, the poverty rate of eight of the nine provinces studied had a positive and significant effect while one other province, Banten, had no significant effect. So, it can be concluded that PMDN in general has a significant effect on reducing poverty in Java, Bali and Nusa Tenggara.
\end{abstract}

Keywords: PMDN; Poverty

\section{Introduction}

Governments from all countries in the world are constantly trying to improve the welfare of all their citizens. Various policies are carried out to accelerate the increase in the level of people's welfare while reducing the poverty rate of the community. According to the World Bank, the poor will not be able to provide for fundamental needs such food, clothing, housing, education, and health The percentage of the world's impoverished has risen steadily during the last 38 years. steadily declined from about $42.7 \%$ in 1981 to $7 \%$ in 2019 . According to the World Bank, the category is poor if a person's income level averages below $\$ 3.2$ per day or below 45,700 rupiah per day. Extreme poverty when the average earnings per day are below $\$ 1.9$. Countries where people live in extreme poverty tend to have poor levels of public health [1]. Poverty causes disruption of family functioning [2]. Living in poverty has a negative impact on the entire family [3]. The coronavirus, which began spreading in 2020, has a devastating impact on public health and has serious implications for economic growth and social development. Poverty and extreme poverty due to coronavirus are increasing across the country [6]. Corona virus greatly affects low-income families [7].

Indonesia as a developing country also still faces obstacles how to reduce poverty rates that are still in the poor category. In 2010 the category of poor people in Indonesia was around 
$13.3 \%$ and gradually continued to decline until 2019 to about $9.3 \%$ of the total population of Indonesia. But in 2020 due to the impact of the coronavirus the poverty rate increased to about $10 \%$ of Indonesia's total population [8]. The Indonesian government continues to strive for the poverty rate to continue to decline. One of the efforts made is to continue to encourage investment both those whose funds are sourced from abroad and those sourced from within the country.

Investment sourced from within the country or or Domestic investment (PMDN) is an activity in which domestic investors use domestic capital to invest in the Republic of Indonesia's territory. It can be done by individuals or businesses. PMDN is a type of investment in which a company is built, purchased in its whole, or acquired. PMDN-related rules are based on Investment Law No. 25 of 2007. To make investment easier coordination in Indonesia, the Investment Coordinating Board (BKPM) was formed whose job is to coordinate policies and services in the field of domestic investment in accordance with the laws and regulations. In the period April-June 2021 the amount of domestic investment in all provinces in Indonesia amounted to 106,252 billion rupiah [9]. PMDN has a positive impact on reducing poverty [10]. However, other researchers state that PMDN has no significant influence on the decline in the number of poor people in Indonesia [13].

In connection with differences from some of the previous research results, researchers conducted a study on nine provinces on the islands of Java, Bali and Nusa Tenggara to ascertain whether PMDN had a positive effect on reducing poverty rates across the provinces studied or only had a significant effect on some provinces while in others there was no impact. Furthermore, the results of this study are expected to be a reference to how to reduce poverty through PMDN, especially in provinces that have a positive impact on reducing poverty. The difference between this study and some previous researchers was in the location of the study and the number of provinces studied as well as the timing of more updated data retrieval ranges.

\section{Methodology}

This research uses quantitative methods. The data used is integrated time series data in the form of a panel for 10 years, namely from 2010 to 2019, as well as Cross Section data from 9 provinces on the islands of Java, Bali, and Nusa Tenggara. The reason for the selection of the three islands is also to compare the impact of PMDN for provinces on the island of Java and outside java islands that are likely characteristic economic and socio-cultural characteristics that are also different. Analyze the data using the Least Square Variable Dummy Method. The independent variable is Domestic Investment while the dependent variable is the Poverty Rate. Panel data analysis is more informative, more varied, efficient, can avoid multicollinearity and is more reliable to test cross section and time series data simultaneously and is also able to minimize bias.

\section{Results and Discussion}

\subsection{Model Analysis}

The effect of domestic investment on reducing poverty is analyzed by utilizing data from 9 provinces. The data is a combination of data issued by various relevant Indonesian 
government agencies. The analysis model uses the least square dummy variable (LSDV) panel data regression method, with the following interrelationship equations:

$$
\begin{array}{ll}
\mathrm{Y}_{\mathrm{it}}= & \beta_{0}+\beta_{1} \mathrm{X}_{1} \mathrm{it}+\alpha_{1} \mathrm{D}_{1} \mathrm{i}+\ldots \ldots+\alpha_{9} \mathrm{D}_{9} \mathrm{i}+\mu_{\mathrm{it}} \\
\mathrm{Y}_{\mathrm{it}} & =\text { decrease in poverty } \\
\beta_{0} & =\text { constant } \\
\beta_{1} & =\text { regression coefficient } \\
\mathrm{Di} & =\text { Dummy } \\
\mathrm{X}_{1} \text { it } & =\text { foreign investment. } \\
\mathrm{i} & =\text { Province; } \mathrm{i}=1,2,3 \ldots \mathrm{n} \\
\mathrm{t} & =\text { Period of time; } \mathrm{t}=1,2,3 \ldots \mathrm{It} \\
\alpha_{1-9} & =\text { slope coefficient dummy } \\
\mu_{\mathrm{it}} & =\text { error term. }
\end{array}
$$

\begin{tabular}{|c|c|c|c|c|c|c|c|c|c|c|c|}
\hline \multicolumn{12}{|c|}{ PMDN pada 9 Propinsidi Jawa, Bail, Nusa Teangggar Barat dan Nusa Tenggara T'mur } \\
\hline \multirow[t]{2}{*}{ No } & \multirow[t]{2}{*}{ Provinsi } & 2019 & 2018 & 2017 & 2016 & 2015 & 2014 & 2013 & 2012 & 2011 & 2010 \\
\hline & & Miliar DR . & Niliar IDR & Miliar IDR & Miliar DR & Miliar IDR & Milizar IDR & Miliar IDR & Miliar DR & Millar IDR & Milizar DR \\
\hline 1 & DKI Jakata & 62.095 & 49.097 & 47.262 & 12.217 & 15.513 & 17.812 & 5.755 & 8.540 & 9.256 & 4.599 \\
\hline 2 & $\mathrm{Jawa} \mathrm{Br}$ & 49.284 & 42.278 & 38.391 & 30.360 & 26.273 & 18.727 & 9.006 & 11.384 & 11.194 & 15.800 \\
\hline 3 & Jawa Tengah & 18.655 & 27.475 & 19.866 & 24.070 & 15.411 & 13.602 & 12.594 & 5.797 & 2.738 & 5.853 \\
\hline 4 & DI Yogyakata & 6.299 & 6.132 & 295 & 949 & 362 & 704 & 284 & 334 & 1,60 & 795 \\
\hline 5 & Java Timus & 45.453 & 33.333 & 45.045 & 46.332 & 35.490 & 38.132 & 34.849 & 21.520 & 9.688 & 10 \\
\hline 6 & Banten & 20,708 & 18.638 & 15.142 & 12.426 & 10.710 & 8.081 & 4.009 & 5.118 & 4.299 & 8.084 \\
\hline 7 & Bali & 7.393 & 1.549 & 593 & 482 & 1.250 & 253 & 2.985 & 3.108 & 313 & 313 \\
\hline 8 & Nusa Ten & 3.519 & 4.135 & 5.414 & 1.343 & 348 & 213 & 1.398 & 45 & 42 & 1.806 \\
\hline 9 & Nusa Tenggara Timur & 3.753 & 4.246 & 1.082 & 822 & 1.296 & 4 & 18 & 14 & 1,00 & 0,10 \\
\hline
\end{tabular}

\begin{tabular}{|c|c|c|c|c|c|c|c|c|c|c|c|}
\hline \multicolumn{12}{|c|}{ 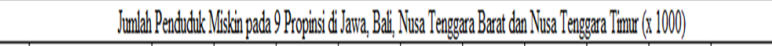 } \\
\hline $\mathrm{N}_{0}$ & Provings & 2019 & 2018 & 2017 & 2016 & 2015 & 2014 & 2013 & 2012 & 2011 & 2010 \\
\hline 1 & DKI Jakata & 365,55 & 373,12 & 389,69 & 384,30 & 398,92 & 393,98 & 354,19 & 366,77 & 363,42 & 312,20 \\
\hline ? & Jara Barat & 3399,16 & 3615,9 & $4.168,4$ & 4224,32 & 4,$435 ;, 0$ & $4,327,07$ & $4.297,04$ & $4,421,48$ & $4,648,63$ & $4,773,70$ \\
\hline 3 & Jara Tengah & $3,73,2,2$ & 3897,20 & $4.40 ; \%$ & $4.56,89$ & $4,57,04$ & $4.836,46$ & $4.732,95$ & $4.863,41$ & 3100,36 & 5369,20 \\
\hline 4 & DI Yogatarata & $48,47^{\circ}$ & 460,10 & 488,53 & 494,94 & 350,22 & 544,87 & 350,19 & 362,11 & 360,88 & 758,20 \\
\hline j & Jara Timir & $4.112,25$ & 433259 & 4.617,01 & $4.703,30$ & $4,789,12$ & $4.786,79$ & 4.771 .26 & $4.960,54$ & $3,356,21$ & $5,599,30$ \\
\hline 6 & Batiten & 654,46 & 660,36 & 675,04 & 688,11 & 70,40 & 622,83 & 666,24 & 648,25 & 690,99 & 577,30 \\
\hline 1 & & 163,85 & 171,76 & 180,13 & 178,18 & 196,72 & $185 ; 20$ & 162,51 & 160,95 & 166,23 & 174,90 \\
\hline 8 & Nisa Tengezar Barat: & 735,96 & 737,46 & 793,78 & 804,45 & 83,89 & $80,82$. & 830,84 & 888,33 & 894,71 & 1009,40 \\
\hline 9 & Nusa Tengegar Timur & $1.146,32$ & $1.142,17$ & $1.150,79$ & 1.149,9,2 & $1.159,84$ & 994,67 & 993,36 & $1,000,29$ & $1.012,90$ & 1014,10 \\
\hline
\end{tabular}

\subsection{Testing Data}

The test used data from nine provinces over ten years by combining time series and cross section data analysis with data panel regression methods that are highly suited to solve economic and business problems [15]. Here is domestic investment data and poverty rate data in 9 provinces in Java, Bali, NTT and NTB Island.

Table 1. Amount of Domestic Investment

Table 2. Poverty Rate in 9 Provinces in Java, Bali, NTT and NTB 


\subsection{Results of Analysis}

The results of the analysis of statistics of LSDV data panel forever province in Java, Bali, NTB and NTT by modeling that poverty increase (Y) and Domestic Investment(X1) and D1, D2... D9 is the1st province until the 9th province. Based on the results of the panel data analysis as shown in Table 3, it is known that overall domestic investment has a positive influence on reducing poverty rates in Java, Bali, NTB and NTT. This is evident from Rsquare's value of 98.75 percent. Value of t-count of 8 provinces is greater than its t-table value $(1,679)$ or the probability of 8 provinces having $\alpha<0.05$. This means that it can be concluded that Domestic Investment (X1) has a positive role in reducing poverty (Y) levels in 8 provinces in Java, Bali, NTB and NTT. The only province whose influence is insignificant is Banten Province (D6) which has a t-count of 1.59 .

\begin{tabular}{|c|c|c|c|c|}
\hline \multicolumn{5}{|c|}{$\begin{array}{l}\text { Dependent Variable: } \mathrm{Y} \\
\text { Method: Panel Least Squares } \\
\text { Date: } 09 / 20 / 21 \text { Time: } 10: 48 \\
\text { Sample: } 20102019 \\
\text { Periods included: } 10 \\
\text { Cross-sections included: } 9 \\
\text { Total panel (balanced) observations: } 90\end{array}$} \\
\hline Variable & Coefficient & Std. Error & t-Statistic & Prob. \\
\hline C & 1091960. & 70175.75 & 15.56036 & 0.0000 \\
\hline $\mathrm{x} 1$ & $-1.38 E-08$ & 2.31E-09 & -5.965585 & 0.0000 \\
\hline D2 & 3839103. & 94255.54 & 40.73080 & 0.0000 \\
\hline D3 & 4019090. & 89680.03 & 44.81588 & 0.0000 \\
\hline D4 & -276937.9 & 92081.95 & -3.007515 & 0.0035 \\
\hline D5 & 4332147 & 96286.76 & 44.99213 & 0.0000 \\
\hline D6 & -138838.1 & 86831.69 & -1.598934 & 0.1138 \\
\hline D7 & -792396.1 & 90088.75 & -8.795728 & 0.0000 \\
\hline D8 & -188613.7 & 93715.81 & -2.012613 & 0.0475 \\
\hline D9 & 50175.70 & 13945.70 & 3.597933 & 0.0006 \\
\hline R-squared & 0.987805 & \multicolumn{2}{|c|}{ Mean dependent var } & 1920066 . \\
\hline Adjusted R-squared & 0.986434 & \multirow{2}{*}{\multicolumn{2}{|c|}{ S.D. dependent var }} & 1903948. \\
\hline S.E. of regression & 221763.0 & & & 27.56105 \\
\hline Sum squared resid & $3.93 E+12$ & \multicolumn{2}{|c|}{ Schwarz criterion } & 27.83880 \\
\hline Log likelihood & -1230.247 & \multirow{2}{*}{\multicolumn{2}{|c|}{$\begin{array}{l}\text { Hannan-Quinn criter. } \\
\text { Durbin-Watson stat }\end{array}$}} & 27.67305 \\
\hline F-statistic & 720.0309 & & & 0.481760 \\
\hline Prob(F-statistic) & 0.000000 & & & \\
\hline
\end{tabular}

The results of the study showing that Domestic Investment has an influence on reducing poverty are in line with research conducted by several other researchers [10]. Based on the results of research in Java, Bali, NTB and NTT we know it is necessary that in general, increasing domestic investment will reduce poverty rates in the majority of provinces in Indonesia. So that the government through the Investment Coordinating Board needs to continuously encourage the creation of a conducive investment atmosphere that will encourage the increase in the amount of investment in all provinces in Indonesia.

\section{Conclusion}

The increase in foreign investment in 9 provinces in Java, Bali, NTB and NTT shows that domestic investment has a significant influence on reducing poverty rates in 8 provinces, the only province that does not have a significant effect on reducing poverty is Banten province. This shows the need for more research to find out the cause why there are provinces that even get PMDN but still have not had an impact on reducing poverty in the province. 


\section{References}

[1] Word Bank (2020). https://www.worldbank.org/en/topic/poverty.

[2] Banovcinova, A., Levicka, J., Veres, M. (2014). The Impact of Poverty on the Family System Functioning. Procedia - Social and Behavioral Sciences, 132.

[3] Dodge KA, Pettit GS, Bates JE. (1994). Socialization mediators of the relation between socioeconomic status and child conduct problems. Child Development, 65, 649-665.

[4] Gerbery, D., Bodnárová, B., Filadelfiová, J. Životné podmienky rodín v medzigeneračnej perspektíve. In Rodina a práca, 1, 52 s. (2007)

[5] Currie, J., Stabile, M. Socioeconomic Status and Child Health: Why Is the Relationship Stronger for Older Children? In The American Economic Review. Vol. 93 (5), pp. 1813 $-1823(2003)$

[6] United Nations. The Social Challenge in times of Covid-19. (2020)

[7] Howes, S. et.al. Poverty in the Pandemic: the impact of coronavirus on low-income families and children. (2020).

[8] OECD (2021). OECD Economic Surveys. Indonesia.

[9] BKPM (2021). https://www.bkpm.go.id/id/statistik/investasi-langsung-dalam-negeriddi

[10] Permana, Y.A. Analisis Pengaruh Pengeluaran Pemerintah, PMDN, PMA, Inflasi dan PDRB Terhadap Kemiskinan di Wilayah Indonesia Bagian Barat Tahun 2010-2016. Universitas Jenderal Sudirman, Purwokerto (2019).

[11] Agustini, Y., Kurniasih, E.P. Pengaruh Investasi PMDN, PMA, dan Penyerapan Tenaga Kerja di Provinsi Kalimantan Barat Terhadap Pertumbuhan Ekonomi dan Jumlah Penduduk Miskin Kabupaten/Kota. Bisnis Ekonomi Jurnal dan Kewirausahaan, Vol. 6, No. 2, 97-119 (2017).

[12] Momongan, J.E. Investasi PMA dan PMDN Pengaruhnya Terhadap Perkembangan PDRB dan Penyerapan Tenaga Kerja serta Penanggulangan Kemiskinan di Sulawesi Utara. Jurnal EMBA: Jurnal Riset Ekonomi, Manajemen, Bisnis dan Akuntansi. Vol.1, No.3 (2013)

[13] Dorojatun, K., Susamto, A.A. Pengaruh Penanaman Modal Asing, Penanaman Modal Dalam Negeri, dan Belanja Dalam Negeri terhadap Tingkat Kemiskinan. Universitas Gadjah Mada (2016)

[14] Baltagi, B.H. Econometrics analysis of data panel 3rd edition. John Wiley \& Sons Ltd., Chichester (2005)

[15] Ekananda, M. Analisis Ekonometrika Data Panel Edisi 2: Teori Lengkap dan Pembahasan Bagi Ekonomi Peneliti, Bisnis Menyeluruh, dan Sosial. Mitra Wacana Media, Bogor (2016).

[16] Jonaidi, A. Analisis Pertumbuhan Ekonomi dan Kemiskinan Indonesia. Jurnal Kajian Ekonomi. No.1, Vol.1. (2012). 